\title{
E.J. Echeverria
}

\section{HIERARCHY OF TRUTHS REVISITED}

\begin{abstract}
This article explores the ecumenical significance of the notion of hierarchy of truths introduced at the Second Vatican Council. With some assistance from the great Reformed master of dogmatic and ecumenical theology, G.C. Berkouwer, I show how there exists an order of priority or hierarchy among truths resulting from their different relation to the foundation of the Christian faith; how this hierarchy helps us to understand better what unites and divides Christians in matters of doctrine; why this notion is wrongly interpreted as a justification of doctrinal indifference, and the substantive role it may play in ecumenical dialogue when the distinction between truth and its formulations is properly drawn.
\end{abstract}

\section{INTRODUCTION}

Our thoughts about the future of the Church must come out of tensions in the present, tensions that must creatively produce watchfulness, prayer, faith, and commitment, love for truth and unity, love for unity and truth. ${ }^{1}$

In Pope Francis' 2013 Apostolic Exhortation, Evangelii gaudium, he remarks in several paragraphs on the nature of ecumenical dialogue (§§244-246). In this article revisiting the notion of hierarchy of truths, I would like to

1 Berkouwer (1964:316; 1965:250). Further references to the latter book will be cited parenthetically in the text as VCNT. The phrase "nieuwe theologie" (literally "new theology") in the Dutch title of the book is a clear reference to the nouvelle théologie of Henri de Lubac, Yves Congar, et al. That reference is lost in the English translation, which speaks of "New Catholicism". The Dutch Reformed theologian Heiko Oberman (1930-2001) describes Berkouwer's book on Vatican II as "breathtakingly important" (1968:388).

Prof. E.J. Echeverria, Research Fellow, University of the Free State, Bloemfontein, South Africa; Professor of Philosophy and Systematic Theology, Graduate School of Theology, Sacred Heart Major Seminary, Detroit, Michigan, USA. E-mail: echeverria. eduardo@shms.edu. 
take as my starting point the remark he makes regarding the ecumenical significance of this notion. He states:

If we concentrate on the convictions we share, and if we keep in mind the principle of the hierarchy of truths, we will be able to progress decidedly towards common expressions of proclamation, service and witness (\$246).

Given the nature of his exhortation, Francis leaves unexplained how we are to understand the ecumenical significance of this notion. In what follows, I shall attempt to explain its ecumenical significance - with a little ecumenical help from the great Dutch Reformed master of dogmatic and ecumenical theology, G.C. Berkouwer (1903-1996).

\section{CHORUS OF VOICES}

Pope Francis joins the chorus of voices, which include luminaries such as G.C. Berkouwer, ${ }^{2}$ Oscar Cullmann, and Karl Rahner, ${ }^{3}$ regarding the Roman Catholic Church's bold, new approach to ecumenism in Vatican II's Unitas redintegratio ("Decree on Ecumenism"), which represents a significant breakthrough, especially in view of one of its key principles, namely, the "hierarchy of truths". This stated principle regarding the hierarchy of truths was not only unexpected but also, says Berkouwer in his second Vatican II book, Retrospective of the Council, "a highly remarkable viewpoint brought in direct connection with the ecumenical problematic":4

2 For Berkouwer's reflections on the ecumenical significance of the hierarchy of truths, cf. Berkouwer (1968:106-111). Further references to this book will be cited parenthetically in the text as NC.

3 Oscar Cullmann (1965:93) maintains that "this text sets forth for all time a completely new concept of ecumenism - new at any rate from the Catholic point of view". Berkouwer cites Cullmann as having said about the hierarchy of truths, "perhaps one of the most promising among all the texts of the council, although curiously so little is said about it" ("vieleicht eine der meistversprechenden unter allen Texten des Konzils, obwohl merkwurdigerweise so wenig von ihr gesprochen wird" (Berkouwer 1968:102 n 78). Rahner similarly wrote regarding the "hierarchy of truths" that "allen Texten des Konzils, obwohl merkwurdigerweise so wenig von ihr gesprochen wird" (Berkouwer 1968:102 $\mathrm{n}$ 78). Rahner similarly wrote regarding the "hierarchy of truths" that this notion was "of fundamental importance for the contemporary situation of faith and one of the really great acts of the Council" ("von fundamentaler Wichtigkeit auch fur die gesamte Glaubenssituation der Gegenwart" and "eine der wirklichen Grosztaten des Konzils" [also cited in Berkouwer]).

4 Berkouwer (1968:102). If anything, Cullmann (1965:94) went further than Berkouwer, calling this statement "the most revolutionary to be found, 
The way and method in which the Catholic faith is expressed should never become an obstacle to dialogue with our brethren. It is, of course, essential that the doctrine should be clearly presented in its entirety. Nothing is so foreign to the spirit of ecumenism as a false irenicism, in which the purity of Catholic doctrine suffers loss and its genuine and certain meaning is clouded. At the same time, the Catholic faith must be explained more profoundly and precisely, in such a way and in such terms as our separated brethren can also really understand. Moreover, in ecumenical dialogue, Catholic theologians standing fast by the teaching of the Church and investigating the divine mysteries with the separated brethren must proceed with love for the truth, with charity, and with humility. When comparing doctrines with one another, they should remember that in Catholic doctrine there exists a "hierarchy" of truths, since they vary in their relation to the fundamental Christian faith. Thus the way will be opened by which through fraternal rivalry all will be stirred to a deeper understanding and a clearer presentation of the unfathomable riches of Christ. ${ }^{5}$

In this paragraph, two matters must be highlighted. First, there is an order of priority or hierarchy among truths resulting from their different relation to the foundation of the Christian faith ("faith in the triune God, One and Three, and in the incarnate Son of God, our Redeemer and Lord") (UR §12). Secondly, attending to this hierarchy of revealed truths helps us understand better what unites and divides Christians in matters of doctrine. Two points need to be emphasized if we are to understand properly what is meant by a "hierarchy of truths", namely the nature of the order of priority and there is no quantitative reductionism in this hierarchy. Let me briefly explain each of these points. ${ }^{6}$

\section{ORDER OF PRIORITY}

Christian truths are viewed in relationship not only to each other, but also chiefly in respect of the central truths of the Christian faith. The nature of this relation is such, Rahner rightly states, that

not only in the Schema de oecumenismo but in any of the schemas of the present Council".

5 Unitatis Redintegratio, §11. Further references to this document will be cited parenthetically in the text as UR. For a helpful account of the Decree on Ecumenism, Unitatis Redintegratio, cf. Morerod (2008:311-341). For an account of the historical origin of the term "hierarchy of truths" before Vatican II and twenty years afterwards, cf. Henn (1987:439-471; 1994:425-427); Guarino (1993:138-161); Congar (1984:107-33); Rahner (1988:162-167, 561-571).

6 Sections 3 to 5 draw on material presented in Echeverria (2013:101-108). 
one can first of all quite properly say that it consists of the fundamental truths of faith, those truths, therefore, on which everything else is based and which themselves are not actually derived from other truths. ${ }^{7}$

Following Rahner, I shall call this an "'objective' hierarchy of truth" (Rahner 1988:165). Thus, the Immaculate Conception of Mary and papal infallibility derive their justification from foundational truths such as the Trinity and the Incarnation. For example,

the dogma of Mary's Immaculate Conception, which may not be isolated from what the Council of Ephesus declares about Mary, the Mother of God, presupposes before it can be properly grasped in a true life of faith, the dogma of grace to which it is linked and which in its turn necessarily rests upon the redemptive incarnation of the Word. ${ }^{8}$

The upshot of the objective hierarchy of truths is that any truth of divine revelation - the entire hierarchy - must be connected to the foundations of the Christian faith.

\section{NO REDUCTIONISM}

It is unclear exactly how attention to the hierarchy of truths helps us have a better estimate of what divides Christians. Berkouwer notes,

It is not enough to merely gauge the meaning and scope of this expression. It is undoubtedly flabergasting that this 'concentration' (on the fundamentals) that pretty much occupies all churches today is unexpectedly set forth in a conciliar decree and that this did not elicit more opposition despite its 'strangeness' (NC, 103).

Indeed, that lack of clarity led to misunderstanding the hierarchy of truths in a "quantitative" fashion, as if a reduction of Christianity to its essential content was the point of the hierarchy. In this regard, the "hierarchy of truths" is taken to mean ranking truths in the order of their importance such that there was a reduction of some truths to ultimate importance and other so-called secondary truths to relative importance, hence authorizing their exclusion. ${ }^{9}$

7 Rahner (1988:164). Cf. also, Congregation for the Doctrine of the Faith (1973:§4).

8 Secretariat for Christian Unity, 15 August 1970, cited in Congar (1984:128).

9 Helpful in formulating this point is Vandervelde (1988:79). This article deals with what some consider to be perhaps the most important document ever produced by the World Council of Churches, Baptism, Eucharist and Ministry. 
Consequently, so it was said, we may adopt an attitude of indifference regarding those truths lower in importance in that hierarchy with respect to the foundation of our faith, say, the Assumption of Mary. In other words, the latter could no longer remain a church-dividing issue because of its low rank - nonfundamental truths - with regard to the foundation of faith and hence the fundamental revealed truths at its base. This interpretation of the hierarchy is evident in the following passage: "A hierarchy of truths implies that an ecumenical consensus need not take place in every detail but, rather, on the more basic and fundamental truths of Christianity" (Livingston et al. 2006:246-247).

But this interpretation of the hierarchy of truths is mistaken, as Berkouwer himself notes, because it breeds theological indifference: "Hierarchy is the very opposite of indifferentism" (NC, 108). As Kasper correctly notes, "the axiom of the hierarchia veritatum is a principle of interpretation rather than a principle of reduction" (Kasper 2015:363 $\mathrm{n} 72$ ). Thus, the hierarchy of truths is not about separating non-negotiable teaching from optional teachings of the Church. Rather, it brings an integral perspective to bear upon the whole body of truths by considering the question of their interconnectedness with the central mystery of Christ and the Trinity. Berkouwer explains:

In the first place, embedded in this expression in the decree is the question of the connection that binds together the 'elements' of doctrine, and above all the 'nexus' with Christ as the foundation, and of the variation in the connection with this foundation. ... The background of the hierarchy of truths lies in the perception that in the doctrine of the Church one can speak about the center, about the fundamental mystery of salvation, and also about the fact that not everything that the Church teaches can be called central in the same sense and without nuance $(N C, 103)$.

In other words, the fundamental issue of the hierarchy is the question regarding the relation of all revealed truths to the foundation of the Christian faith, the Christological concentration, as Berkouwer and others have called it (NC, 102, 106 \& Kasper 1980:99-104).

This conclusion should not lead us to overlook the legitimate sense in which some truths are weightier than others. Most important, the last consideration is a material principle - Christological concentration - that is, a principle of interpretation, not a selective principle (Kasper 1980:103). As Walter Kasper explains:

It may even be - and has indeed often been in the history of the Church - that fundamental principles have been resolved on the 
basis of relatively peripheral questions. At the Council of Ephesus in 431, for example, the true incarnation of God was discussed on the basis of the title 'Godbearer' (Theotokos). The so-called peripheral truths should therefore not be treated with indifference (Kasper 1980:103-104).

\subsection{In what sense are some truths more fundamental than others?}

Furthermore, this mistaken interpretation implies an opposition between the hierarchy of truths of Vatican Il's "Decree on Ecumenism" and Pius XI's 1928 Encyclical Mortalium Animos.

In the encyclical 'Mortalium animos' the distinction between 'capita fundamentalia' and 'capita non-fundamentalia' is rejected. The value of this kind of distinction was opposed with the question of whether God had not revealed all truths, thus without nuancing them (NC, 101).

In his own words, Pius XI wrote:

In connection with things which must be believed, it is nowise licit to use that distinction which some have seen fit to introduce between those articles of faith which are fundamental and those which are not fundamental, as they say, as if the former are to be accepted by all, while the latter may be left to the free assent of the faithful: for supernatural virtue of faith has a formal cause, namely, the authority of God revealing, and this is patient of no such distinction. For this reason it is that all who are truly Christ's believe, for example, the Conception of the Mother of God without stain of original sin with the same faith as they believe the mystery of the August Trinity, and the Incarnation of our Lord just as they do the infallible teaching authority of the Roman Pontiff, according to the senses in which it was defined by the Ecumenical Council of the Vatican. Are these truths not equally certain, or equally to be believed, because the Church has solemnly sanctioned and defined them, some in one age and some in another, even in those times immediately before our own? Has not God revealed them all? (Pius XI 1928:§9).

Pius' point is, essentially, that all revealed truths must be held with the same divine faith, because they are revealed and the Church infallibly declares them to be true. Archbishop Andrea Pangrazio of Gorizia (Italy) made this very point to the Council in its discussion of the schema of ecumenism, November 1963, when he introduced the principle of the "hierarchy of truths" (as cited in Morerod 2008:322-323). Still, Archbishop 
Pangrazio did not fail to add that some of these truths are more important than others. More important, in what sense?

We can get at that sense by following a distinction first drawn by Herbert Mühlen between a "doctrine's content from the authority with which it is proposed". Alternatively put, in the words of Thomas Guarino, "the distinction is between centrality to the foundation of the faith as opposed to the certainty with which the Church teaches it". In this regard, dogmas, such as the Immaculate Conception (1854) and Mary's Assumption (1950), may be very high in certainty, but "relatively low with regard to the central truths of the Christian faith" (Guarino 1993:142-143). Therefore, some revealed truths may be important, because they provide the foundation to nonfoundational teaching; in that regard, they are central to the Christian faith. Indeed, as Mysterium Ecclesiae reiterates, "all dogmas, since they are revealed, must be believed with the same divine faith". But what kind of ecumenical importance does this emphasis leave us with? Are we back to Pius XI, unable to make a distinction "between the act of faith by which a Christian believes in the Incarnation and that of the infallible papal magisterium[?]"(Guarino 1993:147). I do not think so. Congar's respectful criticism of Mortalium Animos is apt in this instance:

\begin{abstract}
While valid on its own level, Pius Xl's criticism does not quite accord with reality. It is somewhat one-sided. Faith can be considered from two perspectives, either from that of its content, the objects to which it relates - I would say the quod - or from that of the formal motive, that is to say, what motivates us to believe - one might say the quo. ... From this point of view it is clear that the mystery of the holy Trinity is more fundamental and more important for the nature of Christianity than that of the Immaculate Conception, and the mystery of the incarnation more fundamental and more important than the infallibility of the papal magisterium $!^{10}$
\end{abstract}

Thus, we can hold on to Pius' point - that all revealed truths must be held with the same divine faith, because they are revealed - without forfeiting the distinction between foundational and nonfoundational teachings. We may do so by focusing on the distinction between the certainty with which the Church teaches, the quo or formal authority infallibly declaring this or that dogma, and the centrality of content, the quod or material content of a doctrine. In terms of the former, we can now say that all revealed truths are equal; but, in terms of the latter, we can say that some truths are more

10 Congar (1984:119). For his discussion of types of onesidedness, cf. Congar (2011:208-213). For a brief account of Congar's view of the hierarchy of truths, cf. Henn (1987:454-455). 
fundamental and more important than others. In this sense, then, there is no inconsistency between Unitatis Redintegratio and Mortalium Animos.

\subsection{Ecumenical implications}

What, then, are the practical implications of the idea of a "hierarchy of truths" in an approach to ecumenical dialogue where significant theological differences remain between Reformed and Catholic Christians in their advancement of unity in truth? (NC, 108). The most important implication is that the hierarchy of truths is essential for discerning the extent of agreement between us regarding the foundations of faith as well as the basic differences that remain on particular issues. Properly understood, using the "hierarchy" also illustrates the revealed truths that vary in importance, depending on their closeness to that foundation. These so-called peripheral truths, such as the four Marian dogmas, are not negotiable, and hence we are not indifferent to them. Still, the question arises as to how exactly we deal with these differences in ecumenical conversation when, for the Church, they remain church-dividing issues. This, too, is Berkouwer's question:

The question can come up, then, of whether believers, Catholic and non-Catholic, cannot find one another in confessing the central doctrines and of whether a marked difference in 'weight' and importance does not exist within the circle of the Church's doctrines, for example, between the doctrines of the seven sacraments and the hierarchical structure of the church, and the doctrine of the incarnation as the central, major mystery of the faith. In this way, exclusive attention to the ranking order is placed ahead of the breadth of doctrine; and ranking order of doctrine is not fixed arbitrarily, but from the perspective of proximity to the center. One could ask the question of whether the idea of a hierarchy of truths in the Roman Catholic system of doctrine is not a huge risk ... now that this 'ranking order' will need to be subjected to the judgment of other churches in connection with their 'proximity' and believing connection to Christ as the foundation (NC, 104).

Berkouwer does not mention what risk he has in mind. But one can surmise from everything else that he states that the risk is that the "hierarchy of truths" is misused in such a way that those truths, socalled peripheral ones, having less weight in the hierarchy, will somehow be treated with indifference. We may counter this misuse in ecumenical dialogue by keeping our focus on the relation of a stated teaching to the foundation, of proximity to the center, showing the sense in which it derives its justification from that foundation. 
In this regard, Berkouwer's student, the late Canadian Reformed ecumenist, George Vandervelde, rightly notes:

[T]he discussion of differences must remain open and move toward greater agreement concerning the core of faith. ... Precisely such a notion as the 'hierarchy of truths' can help maintain the ecumenical dynamic in the face of differences. This notion can break through a static fixation of 'basic differences' by constantly forcing dialogue partners to the unity that is to be found in the 'foundation of faith', while at the same time opening up the possibility of articulating the confessional expression of that unity (Vandervelde 1988:83-84).

Putting into practice Vandervelde's ecumenical proposal requires that the Catholic ecumenist be clear that the Church rejects ecclesiological relativism ("all churches are basically the same"), false irenicism (a false conciliatory approach), doctrinal indifferentism ("doctrine divides"), a common denominator ecumenism ("mere Christianity"), and, last but not least, ecumenical dialogue when it is understood as a negotiating or cognitive bargaining of doctrines ("these doctrines are non-negotiable as opposed to more peripheral aspects of Catholic teaching").

Of course, in order to move beyond a static fixation of basic differences, Catholic ecumenical dialogue requires that we "understand the outlook of our separated brethren", as the Decree on Ecumenism states.

Study is absolutely required for this, and should be pursued with fidelity to truth and in a spirit of good will. When they are properly prepared for this study, Catholics need to acquire a more adequate understanding of the distinctive doctrines of our separated brethren (UR §9).

Maintaining the ecumenical dynamic requires that we understand and practise authentic ecumenism as a gift of God's grace that is at the service of truth. ${ }^{11}$ The journey of ecumenical dialogue is thus an ongoing "dialogue of conversion", on both sides, trusting in the reconciling power of the truth, which is Christ, in order to overcome the obstacles to unity. The ground motive of this dialogue for reconciliation is "common prayer with our brothers and sisters who seek unity in Christ and in His Church" (UUS §24). John Paul II adds: "Prayer is the 'soul' of the ecumenical renewal and of the yearning for unity". Briefly, it is the basis and support for everything the [Second Vatican Ecumenical] Council defines as 'dialogue"' (UUS §28).

Sometimes dialogue is made more difficult, indeed impossible, when our words, judgements, and actions manifest a failure to deal with each

11 John Paul II (1995:§39). Hereafter in the text UUS. 
other with understanding, truthfully and fairly. "When undertaking dialogue, each side must presuppose in the other a desire for reconciliation, for unity in truth" (UUS §29). A necessary sign of this dialogue is that we have passed from "antagonism and conflict to a situation where each party recognizes the other as a partner" (UUS §41). In that case, an authentic inter-confessional dialogue is made possible, because each confessional interlocutor recognizes the other as an ecumenical partner, as a fellowbeliever in Christ, in the common cause of the Gospel, especially regarding the issue of the visible unity of the Church. In short, the ecumenism of conversion embodies the conviction that is expressive of a receptive ecumenism in which "dialogue is not simply an exchange of ideas. In some way it is always an "exchange of gifts"', indeed a "dialogue of love" (UUS §§28-29).

In this connection, I shall distinguish three dimensions in the work of ecumenism following the Congregation for the Doctrine of the Faith in its "Doctrinal Note on some Aspects of Evangelization". This Doctrinal Note states:

\begin{abstract}
Above all, there is [1] listening, as a fundamental condition for any dialogue, then, [2] theological discussion, in which, by seeking to understand the beliefs, traditions and convictions of others, agreement can be found, at times hidden under disagreement. Inseparably united with this is another essential [3] dimension of the ecumenical commitment: witness and proclamation of elements which are not particular traditions or theological subtleties, but which belong rather to the Tradition of the faith itself (Congregation for the Doctrine of the Faith 1973:§12).
\end{abstract}

In the first instance, then, listening means letting your ecumenical interlocutor speak for himself as a partner. Let me give an example of listening. In the graduate course that I teach on theological method at Sacred Heart Major Seminary, I regularly assign a research paper on topics in ecumenical theology, for example, sacramental theology, the theology of the Eucharist or Baptism. I urge the students to listen to John Calvin ${ }^{12}$ and other contemporary Reformed theologians such as Herman Bavinck (Bavinck 2008:461-585; 1901:441-563) and G.C. Berkouwer ${ }^{13}$ on their sacramental theology and hence their understanding of, say, Eucharistic presence. Listening means, I explain, not to bring to their reading of these authors from the outset the dilemma of symbol or reality. If they do, they

12 John Calvin (1536): Book IV, Chapter XIV, nos. 1-16; Chapter XVII, nos. 1-50, especially no. 10.

13 Cf. Berkouwer (1954:270-326), particularly Chapter 10 on Eucharistic presence, "Symbol or reality," and Chapter 11, "Real presence"; 1969:202-243. 
will be neither in a favourable position to understand the sense in which these theologians affirm a version of sacramental realism or, in turn, to discuss responsibly their theological views.

Given the limitations of this article, I cannot enter into Berkouwer's critique of the specious dilemma of symbol or reality in Reformed sacramentology. Berkouwer defends a Reformed version of "Real Presence" in the Eucharist, affirms the sacramental significance of the signs of bread and wine and the connection between them and that which is signified, namely the body and blood of Christ, resulting then in the defence of a Reformed understanding of "sacramental realism". This results in his definitive rejection of understanding Christ's presence as merely a spiritual presence. I urge my graduate students to note that genuine CatholicReformed ecumenical dialogue cannot ignore Berkouwer on this matter of Catholic sacramentology and his ecumenical dialogue from the standpoint of a Reformed sacramentology. In particular, Berkouwer takes seriously the fundamental question that informs his dialogue with Catholics: what "grounds the conjunction between the sign and the signified firmly in the acts of God". Berkouwer's answer to this question advances the discussion between Catholics and Reformed Christians:

This is to reject the automatic conjunction which depersonalizes the sacrament, but also to reject the notion of the mere sign in itself, for through the Spirit because of its institution by God the sign is full of efficacy with respect to faith. That is why the per sacramentum and the cum sacramentum can be accepted simultaneously without involving us in contradictions.

Furthermore, Berkouwer advances the ecumenical dialogue on sacramentology, particularly the fundamental matter of Eucharistic presence, because he understands that the crux of the matter between Catholic and Reformed sacramentology "is not a difference between praesentia realis or not, but a difference regarding the mode of this presence" (Berkouwer 1969:101-102). Most important, this conclusion permits us to underscore one of the main claims of Vatican II's Decree on Ecumenism, namely that listening opens one up to understanding that

sometimes one tradition has come nearer than the other to an apt appreciation of certain aspects of a revealed mystery, or has expressed them in a clearer manner. As a result, these various theological formulations are often to be considered as complementary rather than conflicting (UR §17). ${ }^{14}$

14 The council is speaking, in this paragraph, about the relationship of Catholicism and Orthodoxy. I am applying this point about complementary theological 
I am of the opinion that this is what the doctrinal note means in stating that sometimes the ecumenical dynamic will be maintained by finding agreement that, at times, is hidden under disagreement.

Furthermore, inseparably united with listening is the necessity of theological discussion, of comparing and contrasting different theological viewpoints, and of critically examining disagreements that are obstacles to full visible unity with the Church, and hence dialogue - with the two dimensions of listening and theological discussion - is a means for resolving doctrinal disagreements and determining whether the beliefs of our ecumenical interlocutor are true or false in light of the authoritative sources of the faith (UUS §35). Hence, ecumenical apologetics is also a dimension of theological discussion.

Finally, again following the recent doctrinal note regarding some aspects of evangelization, there is the third dimension of witness and proclamation. In other words, as I understand the doctrinal note, it urges us to distinguish witness and proclamation of the truths that belongs to the Tradition of the faith (e.g., "Real Presence") itself rather than elements that are particular traditions, say Aristotelian Thomism, or theological subtleties (concepts of substance/accidents), which are expressed in various theological formulations. This third dimension is, arguably, based on the distinction between truth and its historically conditioned formulations, between form and content, propositions and sentences, which was invoked by John XXIII in his opening address at Vatican II, Gaudet Mater Ecclesia. The pope made this distinction between truth and its formulations in a famous statement at the beginning of Vatican II:

The deposit or the truths of faith, contained in our sacred teaching, are one thing, while the mode in which they are enunciated, keeping the same meaning and the same judgment [eodem sensu eademque sententia], is another.

The subordinate clause in this passage is part of a larger passage from Vatican I, Dei Filius (Denzinger 3020), and this passage is itself from the Commonitorium primum 23 of the $5^{\text {th }}$-century monk, Vincent of Lérins (died c. 445):

Therefore, let there be growth and abundant progress in understanding, knowledge, and wisdom, in each and all, in individuals and in the whole Church, at all times and in the progress of ages, but

formulations to Catholicism and Reformed theology (in particular, Bavinck and Berkouwer). I (Echeverria 2013:20-109) develop this application to CatholicReformed ecumenical dialogue in my book, Berkouwer and Catholicism. 
only with the proper limits, i.e., within the same dogma, the same meaning, the same judgment.

We can thus say with justification that John XXIII framed the question regarding the nature of doctrinal continuity in light of the Lérinian thesis, which was received by Vatican I, namely that doctrine must progress according to the same meaning and the same judgement (eodem sensu eademque sententia), allowing for legitimate pluralism and authentic diversity within a fundamental unity. ${ }^{15}$

Let me be clear that the distinction between truth and its theological formulations is not made because inadequacy and incompleteness of expression lead to inexpressibility of truth, as if to say that truth can never be expressed determinatively. No, theological formulations must bear some relationship to truth, because language, and the theological propositions it expresses, has a proper function of referring to reality, some state of affairs. ${ }^{16}$ In other words, judgements expressing propositions are true, because they correspond to reality; they are as true judgements an "adequatio intellectus et rei", corresponding to what is, and hence "a claim to the possession in knowledge of what is" (Mansini 2000:242). But, however important the question of truth is and the proper function of propositions referencing reality, ${ }^{17}$ it is not merely a question of a "bare adequatio" between propositions and reality. Rather, Christians are called to be engaged in effectively communicating the Christian faith. John Paul rightly states:

Because by its nature the content of faith is meant for all humanity, it must be translated into all cultures. Indeed, the element which determines communion in truth is the meaning of truth. The expression of truth can take different forms. The renewal of these forms of expression becomes necessary for the sake of transmitting to the people of today the Gospel message in its unchanging meaning (UUS §19).

15 In this instance, I cannot address the question, as Wainwright (2000:26) has put it, "of just how wide a pluralism of theological interpretation may become before it sinks into dogmatic indifferentism". I discuss this question in "'Ressourcement', 'Aggiornamento', and Vatican II in Ecumenical Perspective” (2014). For a fuller treatment of the question of authentic diversity within a fundamental unity, cf. my book, Berkouwer and Catholicism (Echeverria 2013:20-109).

16 I develop this point at length in my article (Echeverria 2012).

17 Wainwright (2000:25) rightly remarks that "the nature of Christian truth requires that language and substance be held together ... in cognitive propositions which hitherto divided churches may together affirm". 
Notice that John Paul does not hold the truth itself to be variable with time and place, but only the formulations.

Although I cannot argue this point in this instance, I opine that making the distinction between truth and its formulations in the sense I have explained above also has ecumenical significance. ${ }^{18}$ Both Vatican II's Unitatis redintegratio and John Paul Il's Ut unum sint held this position. Thus, it is not surprising that the doctrinal note does so as well.

I have argued elsewhere that Berkouwer was also persuaded of the ecumenical import of this distinction (Echeverria 2014). In Berkouwer's 1964 ecumenical study, Vatikaans Concilie en de nieuwe theologie (Berkouwer 1964:Chapter 3), which was his first book on Vatican II, he is especially concerned to show the influence of nouvelle théologie on the discussions of Vatican II. The crux of the relevance of nouvelle théologie, not merely for the Catholic Church, but also for the Reformed tradition is, according to Berkouwer, to be found in its conviction that a distinction could be made between truth and its formulations in dogma, between form and content, content and context, a distinction that made possible internal renewal within the Catholic Church by virtue of rediscovering the riches of the sources of the Christian faith. Berkouwer rejected the relativistic implications that some drew from this distinction. In the last year of the Second Vatican Council (1965), Berkouwer was asked in an interview whether he regarded himself to belong to the Catholic renewal movement of the nouvelle théologie. He replied:

There are very many valuable new elements in the nouvelle théologie: the growing conviction that theology can never be finished; that the Word of God is inexhaustible; that we see through a glass, darkly (1 Cor 13:12); and that we must live with the awareness that theology cannot exist by repeating the formulations that were at one time expressed (Puchinger 1965:308).

In sum, these elements helped contribute to a renewal that "can be an authentic enrichment of our understanding of unchangeable truth" in order to meet truly the contemporary challenges faced by the Church. Thus, according to Berkouwer, the distinction between truth and its formulations highlights in the approach of the nouvelle théologie "the abundant richness of God's Word". Indeed, he adds, that point "actually strikes both sides of the divide between Rome and the Reformation" (Berkouwer 1964:76) [ET: 66].

Returning then to the doctrinal note's third dimension of ecumenism, in my judgement, a good example of what this note has in mind is

18 Unitatis Redintegratio refers to this connection with John XXIII's opening address in footnote 27. 
found in Edward Schillebeeckx's 1967 study on Christ's Eucharistic Presence. ${ }^{19}$ Pared down for my purpose in this instance, I want to highlight Schillebeeckx's one point regarding what the Council of Trent taught in its Decree on the Sacrament, especially in the Canons, of the Eucharist about Christ's real presence in the Eucharist. ${ }^{20}$

Schillebeeckx correctly argues that the genesis of these canons reveals three different levels in Trent's definition. The first canon affirms a specific and distinctive Eucharistic presence: the real presence of Christ's body and blood under the sacramental species of bread and wine. He explains:

This is a presence which is understood in so deep and real a sense that Jesus was able to say, This here, this is my body [cf. Luke 22: 19]; I hand it over to you for you to eat, so that you may have communion with me. For this reason, Christ is 'truly, really, and substantially' present. ... The Council of Trent was unable to express this Eucharistic real presence in any other way than on the basis of a change of the substance of bread and wine into the substance of Christ's body and blood (canon 2).

The question that immediately arises concerns the relationship between the first and second canon. Briefly, Schillebeeckx argues that, because a real ontological change of one substance into another is entailed by the real Eucharistic presence of Christ, therefore "this change of bread and wine was very suitably ['fittingly', 'most appropriately'] called transubstantiation (the concluding sentence of canon 2)" (Schillebeeckx 1967:32-35) [ET:44-45]. This is how Trent chooses to describe the conversion taking place truly, really, substantially (vere, realiter, substantialiter) (Denzinger2012:1636). This conclusion raises the question as to whether a real ontological change of bread and wine - the basic reality of the thing, what it is in itself - a dogmatic requisite of faith? In other words, does it belong to the content of faith, being therefore a true datum of faith?

Schillebeeckx answers yes to this question, but I cannot lay out his reasons now. Still, I must mention his crucial point, namely that, since we are after all not bound by the Church's faith to the philosophical conceptuality of Aristotelian Thomism for expressing the Catholic dogma of Christ's real presence in the Eucharist, we may express that faith into other conceptualities. Consider the circumstance in which a "new interpretation may be necessary because the old interpretations have

19 Schillebeeckx (1967; 1968; 1966). The latter article is an address delivered in French during the fourth session (1965) of Vatican II to fathers of the council at Domus Mariae in Rome.

20 Denzinger (2012:1635-1661), and for the Canons (2012:1651-1661). 
ceased to speak to us within our contemporary experience of faith", as some have argued about the conceptuality used to give an account of transubstantiation. It may also be that in ecumenical dialogue regarding Christ's presence, the mode of presence, and particularly its relation to the bread and wine (to quote the Decree on Ecumenism again), "one tradition has come nearer than the other to an apt appreciation of certain aspects of a revealed mystery", say, the sacramental realism of the Eucharist's Presence of Christ, "or has expressed them in a clearer manner". The upshot is that "these various theological formulations are often to be considered as complementary rather than conflicting" (UR §17). In either case, we must ask whether, as Schillebeeckx rightly notes, "full justice is done to the deepest meaning of the datum of faith". Yes, he adds, it may be true that "No single formulation can exhaust the faith, but this does not make every expression of faith true, meaningful or in accordance with faith" (Schillebeeckx (1967:126) [ET:158].

This important criterion led Schillebeeckx to reaffirm transubstantiation. The latter concept is irreplaceable, because the dogma of Eucharistic presence affirms the substantial change of bread and wine - "This here, this is my body"21 - and hence, according to Schillebeeckx, this dogma
obliges the Catholic to admit the profound realism, or the ontological dimension, of the Eucharistic presence in such a way that after the consecration the reality present is no longer ordinary or natural bread and wine, but our Lord himself in the presence of bread and wine which has become sacramental (Schillebeeckx 1966:332).

This means that notions such as transsignification (change in meaning) and transfinalization (change in purpose) will not capture the ontological dimension - the "metaphysical density" - of Eucharistic presence. Still, the claim that transubstantiation is irreplaceable does not mean that these two latter notions are not essential. The only question is: In what sense. Schillebeeckx replies:

In the Eucharist, transubstantiation (conversio entis-what is the present reality? Christ's body) and transsignification (the giving of a new meaning or new sign) are indissolubly connected, but it is impossible simply to identify them ... Reality is not man's

21 Sokolowski (2006:105-106) rightly remarks: "In the Eucharistic prayer Christ is quoted not as saying, 'This bread is my body', but 'This is my body'. If Christ had said 'this bread' was his body, then the thing referred to would still be bread, but the simple demonstrative pronoun 'this' without a noun implies that it is not bread any longer". 
handiwork - in this sense, [metaphysical] realism is essential to the Christian faith (Schillebeeckx 1967:121) [ET:150-151].

Earlier in his address to the bishops at Vatican II, Schillebeeckx stated:

But in its ontological reality, to the question 'What is this bread
ultimately, what is this wine ultimately?' one can no longer answer,
'Bread and wine', but instead, 'The real presence of Christ offered
under the sacramental sign of bread and wine'. Therefore, the reality
(that is the substance, because that is the meaning of 'substance')
which is before me, is no longer bread and wine, but the real
presence of Christ offered to me under the sign of food and drink. ${ }^{22}$

Thus, Christ offers his intimate presence to us as the revelation of the mystery of God himself, Trinitarian love, by means of his true, real, and substantial presence in bread and wine. These sacramental signs realize his presence:

The bread and wine have become this real presence offered by Christ, who gave his life for us on the cross; offered by Christ in order that we participate in this sacrifice and in the new covenant which is life for us all (Schillebeeckx 1966:337).

In other words, according to the Catholic tradition, the foundation and presupposition of Eucharistic faith - an interpersonal relationship between Christ and us, communion with himself - is that Christ is truly, really, and substantially present in the Eucharist, and hence it is only with respect to the latter that the salvific purpose of that real presence may be realized in which we receive his free gift of salvation - sharing in a perfect communion of love between Father, Son, and Holy Spirit - through communion in his body and blood. It is that saving purpose that belongs to the Tradition of the Faith - to use the language of the doctrinal note - such that we may bear witness and proclaim that Christ's real presence when accepted effects "the union of believers with Christ, and their union with each other in the Church"

22 Schillebeeckx (1966:337). In this context, Schillebeeckx indicates his agreement with Pope Paul's 1965 encyclical, Mysterium Fidei: "As a result of transubstantiation, the species of bread and wine undoubtedly take on a new signification and a new finality, for they are no longer ordinary bread and wine but instead a sign of something sacred and a sign of spiritual food; but they take on this new signification, this new finality, precisely because they contain a new "reality" which we can rightly call ontological" (\$46)."In other words, the encyclical admits transfinalization and transignification on condition that they are not considered as an extrinsic designation or as a peripheral change, but rather as having a profound and ontological content. That is the very meaning of the dogma of transubstantiation" (Schillebeeckx 1966:338). 
(Nichols 2011:76). As St. Paul states, that purpose is realized in Eucharistic unity: "The bread which we break, is it not a participation in the body of Christ? Because there is one bread, we who are many are one body, for we all partake of the one bread" (1 Cor. 10:16-17). Indeed, we must bear witness to and proclaim this Eucharistic union with Christ and his body.

Finally, the Church teaches that

each Catholic has the right and duty to give the witness and full proclamation of his [Eucharistic] faith. ... With non-Catholic Christians, ... Catholics must enter into a respectful dialogue of charity and truth, a dialogue which is not only an exchange of ideas, but also of gifts, in order that the fullness of the means of salvation can be offered to one's partners in dialogue. In this way, they are led to an ever deeper conversion in Christ. ${ }^{23}$

Participating in the real presence of Christ in the Eucharist joins us with the mystery of God himself, Trinitarian love, and hence with the Father, in Christ, through the power of the Holy Spirit. Indeed, the Church's Eucharistic faith is the very mystery of the Church. In this respect, we may conclude with Berkouwer who shares the heart of the ecumenical calling:

The very mystery of the Church invites, rather compels us, to ask about the perspective ahead for the difficult way of estrangement and rapprochement, of dialogue, contact, controversy, and for the ecumenical striving to overcome the divisions of the Church (Berkouwer 1964:316) [ET: 249].

In conclusion, in a theology of ecumenical dialogue the notion of the hierarchy of truths plays a fundamental role. ${ }^{24}$

- Such a theology does not begin with doctrinal differences, but rather with the basis of common ground in the fundamental Christological and Trinitarian statements of faith.

- It attempts then to understand existing theological differences better in light of, and in connection with those fundamental statements, in order to recognize possible convergences beneath the theological differences. We must keep our focus on the relation of a stated teaching to the foundation, showing the sense in which it derives its justification from the foundation.

23 Congregation for the Doctrine of the Faith (2007:§12). Pope Francis (2013:§246): "Through an exchange of gifts, the Spirit can lead us ever more fully into truth and goodness."

24 Helpful on this role, in this instance, is Kasper (2015:306-307). 
- Accordingly, Vandervelde rightly notes,

\begin{abstract}
the discussion of differences must remain open and move toward greater agreement concerning the core of faith. ... Precisely such a notion as the 'hierarchy of truths' can help maintain the ecumenical dynamic in the face of differences. This notion can break through a static fixation of 'basic differences' by constantly forcing dialogue partners to the unity that is to be found in the 'foundation of faith', while at the same time opening up the possibility of articulating the confessional expression of that unity (Vandervelde 1988:83-84).
\end{abstract}

For example, consider briefly the standard Evangelical misunderstanding of the notion of "ex opere operato" found in the recent study of Gregg Allison on Catholic theology, in particular, sacramentology. ${ }^{25}$

Allison (2014:244) emphasizes that, according to Catholic sacramental theology, the sacramental efficacy of grace, in fact, "the ground of its validity ... of the sacraments" is "ex opere operato", which literally means "by the very fact of the action's being performed." He adds that "[t]heir validity is completely attached to their sign, which is virtuous or powerful in and of itself". Given Allison's Zwinglian sacramental theology, he rejects the Reformed, Lutheran, and Catholic teaching that sacraments confer divine grace, but also holds "the question of their validity ex opere operato [to be] a moot one" (2014:245).

Allison (2014:244-245) is wrong in this instance on several counts regarding the dissimilarity between the Reformed theology of the sacraments and Catholic sacramental theology. First, Berkouwer argues that the Reformed objection to ex opere operato ("by the work performed" or "by force of the action itself") should not be posed in term of sacramental efficacy. ${ }^{26}$ According to Berkouwer, the question is not whether the sacraments are objectively efficacious, but rather how they

25 For a critical discussion of Allison's book, see my article, "A Catholic assessment of Gregg Allison's critique of the 'Hermeneutics of Catholicism"” (Echeverria 2015).

26 For Berkouwer's defence of sacramental efficacy, but not ex opere operato, cf. Berkouwer (1954:11-28, 66-107) [ET:13-26, 56-89]. Cf. also Berkouwer (1953:78-88, 93-103); Bavinck (2008:127-142). "With this objective view of the sacrament, Calvin stands decidedly on the side of Rome and the Lutherans. ... [Calvin] can hardly find words strong enough to express his conviction concerning the real, essential, genuine presence of Christ's own flesh and of his own blood in the Lord's Supper. He declares explicitly that the issue between him and his Roman Catholic and Lutheran opponents involves only the manner of that presence" (Bavinck 2008:132). Kuyper (cited by Berkouwer 1954:101-102 [ET:84]] makes a similar point: "The Reformed stand with Rome, 
exercise their efficacy. This is also Bavinck's view and, arguably, the view of Calvin and Luther. If so, therefore, the difference between Reformed and Catholic sacramentology is not at all over the real, objective efficacy of the sacraments, wherein the visible sign is not only expressive, but also effective in communicating grace. But rather it is over "a totally different understanding of what efficacy is" (Berkouwer 1954:74) [ET:62].

Secondly, Allison (2014:245) misinterprets ex opere operato as leading to a view of the sacraments "as being mechanical, impersonal, and effective apart from faith and obedience". His misreading stems from ignoring the explicitly stated Christological foundation of ex opere operato in the Catechism of the Catholic Church. Christ's primary role in the sacraments is foundational:

They [sacraments] are efficacious because in them Christ himself is at work: it is he who baptizes, he who acts in his sacraments in order to communicate the grace that each sacrament signifies. ... This is the meaning of the Church's affirmation that the sacraments act ex opere operato ... by virtue of the saving work of Christ, accomplished once for all (§§1127-1128).

Allison cites $\$ 1127$, but fails to see its meaning for properly understanding ex opere operato. Furthermore, because Allison confuses the crucial difference between principal cause and instrumental cause, with God as the ultimate cause of grace, such that in themselves and apart from God they would not communicate grace, he separates "the power working in the sacraments from their primary fountain, and looked upon them as working of themselves" (Möhler 1997:218 n 2). No wonder that Protestant readings, such as Allison's, lead to the charge that Catholic sacramentology suffers from sacramental automaton, ritualism, juridicism, cheap grace, a deistic view of "ex opere operato", such that the sacraments are divorced from their Christological foundation, that is, "from their proper and sole source, namely from Christ, the true and only giver of grace, and gives them an independent status" (Adam 1996:27). In this light, we can understand why even Edward Schillebeeckx speaks of the very view that Allison rightly rejects, but mistakenly thinks is Catholic, as "the headless corpse of sacramentalism", ${ }^{27}$ implying that the sacraments have been severed from the "Christological foundation of

Luther, and Calvin against Zwingli in their adherence to a divine working of grace in the sacraments".

27 Schillebeeckx (1966:88 n 60). This note and the entire appendix, "St. Thomas' Christological Interpretation of Sacramental Ex Opere Operato Causality" (1966:82-89), is available in the English translation, Christ the Sacrament of the Encounter with God, but not in the original Dutch edition. 
the ex opere operato efficacy". ${ }^{28}$ Of course, these points of convergence between Reformed and Catholic sacramentology do not resolve all the theological differences, but it does show that some of the traditional controverted differences need no longer be construed as basic differences; hence, ecumenical dialogue concerning "ex opere operato" must not be allowed to stagnate.

Thus, Pope Francis was right:

If we concentrate on the convictions we share, and if we keep in mind the principle of the hierarchy of truths, we will be able to progress decidedly towards common expressions of proclamation, service and witness (\$246).

\section{BIBLIOGRAPHY}

ADAM, K.

1996 [1929]. The spirit of Catholicism. Translated by D.J. McCann, O.S.B. Steubenville: Franciscan University Press.

Aluison, G.

2014. Roman Catholic theology and practice: An evangelical assessment. Wheaton: Crossway.

BAVINCK, $\mathrm{H}$.

1901. Gereformeerde dogmatiek, IV. Kampen: J.H. Kok.

2008. Reformed dogmatics, Vol. 4, Holy Spirit, church, and new creation. Edited by J. Bolt and translated by J. Vriend. Grand Rapids: Baker Academic.

2008 [1887]. Calvin's doctrine of the Lord's Supper. Mid-America Journal of Theology 19:127-142.

Berkouwer, G.C.

1953. Ex Opere Operato, Part I. Gereformeerd Theologisch Tijdschrift 53(3):7888; Ex Opere Operato, Part II. Gereformeerd Theologisch Tijdschrift 53(4):93-103. 1954. De sacramenten. Kampen: J.H. Kok.

1964. Vatikaans Concilie en de nieuwe théologie. Kampen: J.H. Kok.

1965. The Second Vatican Council and the new Catholicism. Translated by L. Smedes. Grand Rapids: Eerdmans.

1968. Nabetrachting op het Concilie. Kampen: J.H. Kok.

1969. The sacraments. Translated by H. Bekker. Grand Rapids: W.B. Eerdmans.

28 Schillebeeckx (1963:85). Avery Cardinal Dulles, SJ (2009:1-13, 6), reminds us: "The primacy of Christ's role in the sacraments is the true meaning of the frequently misunderstood term, ex opere operato". 
CALVIN, J.

1536. Institutes of the Christian religion. Translated in 1845 by $\mathrm{H}$. Beveridge. [Online.] Retrieved from: http://www.ccel.org/ccel/calvin/institutes.i.html [2014, 22 September].

Congregation for the Doctrine of the Faith

1973. Mysterium Ecclesiae. [Online.] Retrieved from: http://www.vatican.va/ roman_curia/congregations/cfaith/documents/rc_con_cfaith_doc_19730705_ mysterium-ecclesiae_en.html [2014, 22 September].

2007. Doctrinal note on some aspects of evangelization. [Online.] Retrieved from: http://www.vatican.va/roman_curia/congregations/cfaith/documents/rc_con_ cfaith_doc_20071203_nota-evangelizzazione_en.html [2014, 22 September].

Congar, Y.

1984. Diversity and communion. Translated by J. Bowden. London: SCM Press Ltd.

2011 [1968]. True and false reform in the Church. Translated and with an introduction by P. Philibert, O.P. Collegeville: Liturgical Press.

Cullman, $\mathrm{O}$.

1965. Comments on the Decree on Ecumenism. The Ecumenical Review 17(April):93.

DenZinger, H.

2012. Denzinger. Compendium of creeds, definitions, and declarations on matter of faith and morals. Edited by P. Hünermann, $43^{\text {rd }}$ ed. Translated and edited by R. Fastiggi and A.E. Nash. San Francisco: Ignatius Press.

Dulles, Cardinal Avery

2009. The theology of worship: Saint Thomas. In: M. Levering et al. (eds.), Rediscovering Aquinas and the sacraments (Chicago: Hillenbrand Books), Kindle Version.

ECHEVERRIA, E.J.

2012. Divine revelation and foundationalism: Towards a historically conscious foundationalism. Josephinum Journal of Theology 19(2):283-321.

2013. Berkouwer and Catholicism, disputed questions. Leiden/Boston: Brill.

2014. The accidental protestant. First Things 24(February):41-45.

2014. Ressourcement, Aggiornamento, and Vatican II in Ecumenical Perspective. Homiletic \& Pastoral Review. [Online.] Retrieved from: http://www.hprweb. com/2014/07/ressourcement-aggiornamento-and-vatican-ii-in-ecumenicalperspective/ [2014, 22 September].

2015. A Catholic assessment of Gregg Allison's critique of the 'Hermeneutics of Catholicism'. Called to Communion. [Online] Retrieved from: http://www. calledtocommunion.com/2015/08/a-catholic-assessment-of-gregg-allisonscritique-of-the-hermeneutics-of-catholicism/ [2015, 10 September]. 
FIORENZA, F.S. 2006. Modern Christian thought, the twentieth century. Minneapolis: Fortress Press.

\section{FRANCIS}

2013. Evangelii Gaudium. Apostolic Exhortation. [Online.] Retrieved from: http://w2.vatican.va/content/francesco/en/apost_exhortations/documents/ papa-francesco_esortazione-ap_20131124_evangelii-gaudium.html [2014, 22 September].

GuARINO, T.G.

1993. Revelation and truth, unity and plurality in contemporary theology. Scranton: University of Scranton Press.

Henn, W. O.F.M. Cap. 1987. The hierarchy of truths twenty years later. Theological Studies 48:439-471. 1994. The hierarchy of truths. In: R. Latourelle \& R. Fisichella (eds.), Dictionary of fundamental theology (New York: Crossroad), pp. 425-427.

John PaUl II 1995. Ut unum sint. Encyclical Letter. [Online.] Retrieved from: http:// www.vatican.va/holy_father/john_paul_ii/encyclicals/documents/hf_jp-ii_ enc_25051995_ut-unum-sint_en.html [2014, 22 September].

Kasper, Cardinal W.

1980. An introduction to the Christian faith. New York: Paulist Press.

2015. The Catholic Church: Nature, reality, and mission. London: Bloomsbury.

Livingston, J.C., Fiorenza, F.S., Coakley, S., James, H. \& Evans, JR. 2006. Modern Christian thought. The twentieth century. Minneapolis: Fortress Press.

MANSINI, G. O.S.B.

2000. Dogma. In: R. Latourelle \& R. Fisichella (eds.), Dictionary of fundamental theology (New York: Crossroad), p. 242.

MöHLER, J.A.

1997 [1832]. Symbolism. Translated by J.B. Robertson. New York: Crossroad Herder Book.

MoRerod, C. O.P.

2008. The Decree on Ecumenism, Unitatis Redintegratio. In: M. Levering \& M. Lamb (eds.), Vatican II, renewal within tradition. (New York: Oxford University Press), pp. 311-341.

Nichols, A. O.P.

2011 [1991]. The Holy Eucharist, from the New Testament to Pope John Paul II. Eugene: Wipf \& Stock.

Oberman, $\mathrm{H}$.

1968. Evangelische Theologie, v. 28. 
PAUL VI

1965. Mysterium Fidei. Encyclical Letter. [Online.] Retrieved from: http://www. vatican.va/holy_father/paul_vi/encyclicals/documents/hf_p-vi_enc_03091965_ mysterium_en.html [2014, 22 September].

PIUs XI

1928. Mortalium Animos, Encyclical Letter. [Online.] Retrieved from: http://www. vatican.va/holy_father/pius_xi/encyclicals/documents/hf_p-xi_enc_19280106_ mortalium-animos_en.html [2014, 22 September].

Punchinger, G.

1965. Gesprekken over Rome-Reformatie. Delft: Meinema.

RAHNER, K.

1988. A hierarchy of truths. Theological Investigations, Vol. XXI. Translated by H.M. Riley. New York: Crossroad.

SCHILlebeECKX, E. O.P. 1963. Christ the sacrament of the encounter with God. Translated by P. Barrett, O.P., et al. Oxford/Toronto: Rowman \& Littlefield Publishers.

1966 [1959]. Christus sacrament van de Godsontmoeting. $8^{\text {ste }}$ druk. Bilthoven: $H$. Nelissen.

1966. Transubstantiation, transfinalization, transignification. Worship 40(6):324-338.

1967. Christus tegenwoordigheid in de Eucharistie. Bilthoven: H. Nelissen.

1968. The Eucharist. Translated by N.D. Smith. London/Sydney: Sheed and Ward.

Secretariat for Christian Unity

1970. Reflections and suggestions concerning ecumenical dialogue. In: Y. Congar, 1984. Diversity and communion. Translated by J. Bowden (London: SCM Press Ltd.), p. 128.

SoKolowsKI, R.

2006. Christian faith and human understanding. Washington: Catholic University of America Press.

VANDERVELdE, G.

1988. BEM [Baptism, Eucharist, and Ministry] and the hierarchy of truths: A Vatican contribution to the reception process. Journal of Ecumenical Studies 25(1):74-84.

VATICAN COUNCIL II

1964. Unitatis Redintegratio. [Online.] Retrieved from: http://www.vatican.va/ archive/hist_councils/ii_vatican_council/documents/vat-ii_decree_19641121_ unitatis-redintegratio_en.html [2014, 22 September].

WAINWRIGHT, G.

2000. Is the Reformation over? The Pere Marquette Lectures in Theology 2000. Milwaukee: Marquette University Press. 
World Council of Churches

1982. Baptism, eucharist and ministry. Lima.

Keywords

Hierarchy of truths

Ecumenism

Dialogue

Truth and its formulations
Sleutelwoorde

Hiërargie van waarhede

Ekumene

Dialoog

Die waarheid en die formulering 